\title{
Factors Affecting ESG towards Impact on Investment: A Structural Approach
}

\author{
Satyabrata Aich ${ }^{1}(1)$, Ayusha Thakur ${ }^{2}$, Deepanjan Nanda ${ }^{3}$, Sushanta Tripathy ${ }^{3, *}$ (I) and Hee-Cheol Kim ${ }^{4, *}$ \\ 1 Wellmatix Co., Ltd., Changwon 51395, Korea; satyabrataaich@gmail.com \\ 2 Electronics and Communication Engineering, Delhi Technological University, Delhi 110042, India; \\ ayushathakur23@gmail.com \\ 3 School of Mechanical Engineering, KIIT Deemed to be University, Bhubaneswar 751024, India; \\ deepanjan.nanda@gmail.com \\ 4 Institute of Digital Anti-Aging Healthcare, College of AI Convergence, u-AHRC, Inje University, \\ Gimhae 50834, Korea \\ * Correspondence: sushant.tripathy@gmail.com (S.T.); heeki@inje.ac.kr (H.-C.K.); \\ Tel.: +82-55-320-3720 (H.-C.K.)
}

Citation: Aich, S.; Thakur, A.; Nanda, D.; Tripathy, S.; Kim, H.-C. Factors Affecting ESG towards Impact on Investment: A Structural Approach Sustainability 2021, 13, 10868. https://doi.org/10.3390/su131910868

Academic Editor: Donato Morea

Received: 11 August 2021

Accepted: 27 September 2021

Published: 30 September 2021

Publisher's Note: MDPI stays neutral with regard to jurisdictional claims in published maps and institutional affiliations.

Copyright: (c) 2021 by the authors. Licensee MDPI, Basel, Switzerland. This article is an open access article distributed under the terms and conditions of the Creative Commons Attribution (CC BY) license (https:/ / creativecommons.org/licenses/by/ $4.0 /)$.

\begin{abstract}
Recent disasters have emphasized the need for further action to protect businesses and society from long-term sustainability threats. We believe that the crisis is hastening nascent ESG trends, and that the increased focus on a company's environmental and social impact will last long after crises have passed. We refined three fundamental concepts that guide our thinking on investing based on environmental, social, and governance factors as our approach to sustainable investing has evolved. The ESG factor assessments are more of an inherent aspect of a sound investment process than a separate investment discipline. When ESG variables are considered, the focus is on long-term risk adjusted investment returns. Investors should choose the strategy that best matches with their goals and interests. ESG investing is not a simple yes or no answer. The research gap extracted from the previous studies is to determine the relationship among the influencing factors of ESG and its priority with their driving and dependence capabilities. We used an ISM Approach to uncover the interrelationships and influencing behavior among the elements for considering ESG in investment after conducting a thorough literature research and consulting with experts. Here interpretive structural modeling (ISM) was used to explore the links among such extracted factors and its interdependencies. There was also focus on the short-term and long-term factors to achieve our desired objective. Our research will assist businesses in attracting and obtaining finance. The results of this analysis will be helpful for leaders to understand the impact of ESG on the investment aspects of an organization.
\end{abstract}

Keywords: ESG; investment; critical factors; interpretive structural modeling; strategy

\section{Introduction}

As the era is evolving, we are witnessing unprecedented achievements in various fields, giving rise to various new possibilities every day. With this progression, we are also seeing various new irreversible changes in our lives and environment which if not heeded at the right time can prove fatal to humankind [1]. Developing sustainably is a win-win situation where we and our surroundings grow hand in hand. Since sustainable goals are always long term, their effects are also long term. As our lifestyle is changing according to our sustainable goals, so is our way of investing and earning [2]. Today the word sustainable not only has pivotal roles in our daily lives but also plays an integral part in choosing which company to choose for investing since investing is all about the effect of compounding.

Today, when we are facing a global pandemic where everything is crashing down, even big multinationals are approaching a holistic sustainable approach where they can 
run in the long term so that they are not shut down by the uncertainty of the times. Hence, sustainable investing helps in generating great financial returns and has a good impact on society and the environment $[3,4]$.

"Socially responsible investors" mainly rely on the three broad categories that is ESG (environmental, social and governance). While sorting the selections for investment, an investor is the one who considers whether to incorporate their values and environmental concerns considering the risk and profitability in the decided selection [5]. ESG concerns are growing more widespread as the millennial generation is higher percentage of overall investors. Executive compensation is where ESG investors concentrate their efforts. Despite the complaints, ESG-focused investment is gaining popularity and attracting the majority of investors, particularly millennials [6]. By 2018, an investment asset worth approximately USD 12 trillion was selected using an investing strategy that is socially responsible [7]. As the total pool of investors consists of a majority of millennials, ESG-focused investments are expanding with them. The ESG-focused investment is increasing and by making some moves such as offering ESG-focused exchange-traded funds (ETFs), financial service industries responded to the demand of ESG investments. A rising number of organizations are proudly putting ESG measures in their reported statements or separately in documents and using them as a standard, which is a very positive response [8].

Since people are always looking forward to being more and more sustainable, they want their investment to multiply the same way, as sustainability is becoming the new future [9]. Socially responsible companies are attracting consumers to such a great extent that it has influenced corporate policies eventually leading to long-term changes in the rules by which the market plays. Gone are the times when the investor was only looking at the profits, the current scenario manifests that investors are also interested in the company's ethical aspects. The use of these non-financial parameters is increasing by the investors, which are used for the analysis to identify the profit and growth opportunities. Those non-financial parameters act as abet in deciding how well the returns will be if you invest in a certain company. In a nutshell, it can be said that ESG investing is an interconnected amalgamation of sustainability and financial systems for better profits.

The environment has a great impact on a human at all points of decision-making, hence it plays an important role at each step of life. The mobilization rate is controlled by the environment which is passed by the DNA to each organism [10]. Social is a very import part of the ESG framework and plays significant roles in ESG, but it is not that noticeable. Institution, the promoting or encouraging of people and culture will have an effect on a broad community. Their variety and inclusivity will pave the path for a long-term future. Investment risks are managed considering ESG reports and scorings by the Investors. These scores, reports and ratings make a company's efforts transparent to analyze, reduces risks and creates long-term financial returns for investors [11]. The entire investment team must have a strong grasp of social variables and their consequences, as well as financial and business knowledge [12]. Governance is mandatory in a public sector or business. It perpetuates the efficiency and lacuna in an institution to achieve its objective, and its community relations and perception [13].

After a critical review of a number of literatures related to ESG, there is no attempt towards the interrelationship among the factors of ESG towards investment. Similarly, some studies used different MCDM techniques to achieve their desired objectives but no study has used ISM methodology to find the driving and dependence powers of the selected factors. With this research gap, this study set its objective to find out the structural relationship among the influential factors of ESG towards investment.

After the extensive literature review of past authors' and experts' advice, 10 important factors were derived which affect the ESG towards investment impact. The study used interpretive structural modeling (ISM) to explore the links among such extracted factors and its interdependencies. Finally, a driver-dependence diagram was formed to access the driving and dependence power among the factors. 
The study is framed as follows. Section 2 presents the significance of the investment impact in ESG and critical factors affecting ESG towards investment decision by surveying the literatures of past authors' and experts' opinions. The proposed ISM methodology is discussed in Section 3. Section 4 interprets the results derived from ISM methodology and the managerial implication is outlined in Section 5.

\section{Literature Review}

A literature review is a method of gathering useful information by analyzing and evaluating a set of pre-recorded studies and articles in a methodical and explicit manner. The goal of this study is to determine which ESG elements have an impact on investment. Initially, publications were selected from several databases such as Scopus, Web of Science, Research Gate, and Science Direct in order to find answers to the study questions. Keywords such as ESG, sustainability, social and governance factors, and investment impact, proved to be extremely useful in locating similar studies. The authors read many publications and then thoroughly reviewed and studied the ones that were pertinent to this investigation.

Investment also emphasizes inter-organizational activities with their collaboration, coordination, and cooperation towards sustainability which can be possible through attitude, behavior, and outcome [14]. Investment impact towards sustainability depends on management strategy and management strategy is influenced by artificial intelligence (AI) [15]. The value creation in organization is enhanced by different sources such as AI and machine learning in organizations; alignment of AI tools and information technology (IT) with organizational strategy; AI, knowledge management and decision-making process; and AI, service innovation and value [16]. Importance of interdisciplinary collaboration is also a vital factor for successful implementation of any strategy towards sustainability. Innovative new service development (NSD) is greatly influenced by interdisciplinary collaboration [17]. Similarly, the previous study observed that strategic management, decision making and corporate sustainability are the key pillars of any organization's business strategy [18].

Karus et al. [19] also stated that organizational factors and managerial implications are critical factors to enhance the operational efficiencies of the service sector by various forms of technological implementation. Smart technology, ambient intelligence and technology acceptance are the successful parameters for achieving sustainability for the construction area [20]. Sustainable supply chain management (SSCM) is the key goal for all organizations. To achieve organizational goals, vision, and productivity towards SSCM, organizations should implement the eco design, adoption of green practices, green purchasing, and consideration of environmental factors, including the GSCM methodology [21]. Innovation management (IM), stakeholder engagement (SE), and entrepreneurial development (ED) also help the organizations towards entrepreneurial orientation for sustainability [22]. Digital technologies are used to determine strategic responses through their value creation path. The positive and negative outcomes of this process depend on managing the structural changes and organizational barriers [23].

The following part of the study is classified into two subcategories. The first subcategory presents the work of past researchers regarding the significance of the investment impact on ESG, whereas subcategory two discusses the different factors influencing ESG towards impact on investment.

\subsection{Past Literatures concerning Investment Impact on ESG}

Investment is a wide topic for discussion because everyone needs a good investment for a sustainable life [24]. Today, from someone who has just entered college to a person who is in his forties, everyone is participating in investment because it both acts as savings as well as a side income for some. In this era with soaring prices and temperatures, and where the natural resources are depleting, it is a time to collectively march towards sustainability. Thus, sustainability is also required for our investments to grow exponentially. Hence, sustainability and investment are interdependent and need a good focus [25]. With this new 
and changed attribute towards investing, sustainability has added many new parameters which should be looked upon and acted upon. Some studies focused on investment and factors affecting investment, especially environmental, social and governance (ESG), are discussed based on which the research is being performed. The ESG score plays a significant role in providing information about a company's fundamentals and influencing investor choices [26]. Due to client's demand many investors use ESG. ESG information also filters the new products and simplifies the process for an investor to invest [5,27]. ESG investors look after the analysis of individual companies. In ESG, governance has a close relationship with the quality of management [28].

\subsection{Factors Influencing ESG for Impact on Investment}

Based on past literatures this subsection describes the different crucial factors influencing ESG towards impact on investment.

\subsubsection{Revenue Conservation}

Conservation impacts investments as it intends to generate profit or at worst case return principal and have a positive impact on natural resources and ecosystem, preserving the critical habitat and less constrain on ecological resources [29]. Since ecological changes happen over a while and are not spontaneous, timely and continuous investment is required which in return over a period of time generates profits. Conservation impact should always be an important aspect while investing. An investment made only for financial gain cannot have a conservation benefit as a result [30,31].

\subsubsection{Human Rights}

Human right is a driver which drives the profitability factor. Foreign direct investment (FDI) or investors are mainly attracted by the developing countries that respect human rights [32]. The country consists of its people, wherever and whenever the people of a nation are happy that results in better productivity and hence better results. They are more likely to succeed in their goals hence it attracts more investment as it yields better results compared with others. FDI has been linked to human rights violations that affect the host country's general population. The vice versa is also true, investment also acts as an antidote to human rights [33].

\subsubsection{Good Governance}

Good governance is a major factor as it is a major indicator of the financial stability of a country. In a country that is strong from within and has good financial statistics, people will actively participate in governmental or private schemes because they will be assured that stringent laws are there to protect them in case things go awry. This, in turn, ensures the smooth running of the wheels of the economy where people rather than stagnating their money, continue generating it. This assures that corruption is minimized, and all the needs of the society are met [34]. Political stability and non-violence, government efficiency, laws, and corruption minimization are critical factors of good governance, which is the most crucial parameter for attracting FDI inflow for investment in the host country [35].

\subsubsection{Deforestation and Biodiversity}

Deforestation has halved the area of forest and the rate of deforestation is increasing [36]. Implementing the reducing emissions from forest degradation and deforestation (REFDD) allows for optimizing the benefits of biodiversity. Currently, economy and ecology go hand in hand. Investors must mitigate various information to allocate investments in ways that provide a positive output not only financially but also ecologically. If we invest only for profits, then our survival will be on the line. The climate for investment in forestry in Third World countries is improving. Deforestation is increasing, leading to a loss in biodiversity, and investment is provided the first priority [37]. Biodiversity protection is 
critical in an area, and it can be accomplished by effective activities, public policies, and geotechnologies that can assist in the management of deforestation in protected areas [38].

\subsubsection{Impact on Investment}

Investment is performed based on the ESG scoring of an organization [28]. Analysts can compare and filter data based on environmental, social, and governance (ESG) performance or ratings, and so perceive ESG data as market signals [39]. As the use of ESG investment is growing and attracting many practitioners, we must understand and know about the insight of future evolution in that field. In using ESG data, Investors are motivated more by financial reasons than ethical reasons and that is not surprising where the respondents are institutional investors [27,40].

\subsubsection{Employee Relationship}

Underinvestment takes place when a firm offers only small benefits but in return expects much more effort with respect to benefit from employees [41]. This results in lowering the fairness level by employees, downgrading the trust level between the coworkers and absences ascend, affecting the productivity. So, when firms obtain pliability in employment, this might cause losing high-performing employees. The happier the workforce of an institution or company is, the higher productivity and output are found. This in return creates a good profile for the institution or company which attracts good investments. Hence, employee relationships are a great asset in any sector [42].

\subsubsection{Waste Management and Pollution Control (WMP)}

For at least two millennia, waste management and pollution control have been considered a public duty. While sanitary considerations were paramount at the outset of the first compact settlements, in recent decades, the fast-increasing turnover of materials has become the most pressing waste management challenge [43]. Waste materials and pollution were and always will be a byproduct of industrialization and are not well-promoted, which results in significant amounts of waste being disposed of. We certainly cannot stop industrialization but if we can convert these wastes and pollutants to something useful then it becomes sustainable which does not harm the environment as much. Successful waste management leads to sustainability, further leading to good investments [44].

\subsubsection{Impact on Environment}

The environmental and social aspects of sustainability regulate the sustainable growth. The growth of an institution or company is supported by ESG social management which is very essential [45]. The better the environment response of the company or institution, the better the ESG rating, which is directly proportionate to investment [4].

\subsubsection{Corporate Policies}

The decision making method of an investor is driven by some parameters. Some factors operate as filters when making investment decisions, such as investigating the relationship between investments, decision-making and factors, and firm-level corporate governance [46]. The corporate policies of a nation provide a clear manifesto of the economy of the country which in return also indicates what type of companies and firms can run smoothly there which is a factor for an investor to invest, such as how stringent or how lenient the policies for an investor are. The decision-making process of investors is influenced by the firm-level corporate governance and core behavioral factors [47].

\subsubsection{Green House Emission}

ESG is a sustainability performance measurement used worldwide. Environmental performance receives more attention from investors, and the Nordic countries are all in the top five when it comes to sustainability ranking [48]. Humans engage in some actions that cause us to face issues, such as burning fossil fuels (coal, oil, and natural gas), clearing 
lands, and agriculture, all of which result in an increase in greenhouse gas concentrations. As a result, the concentration of greenhouse gases (GHGs) in the atmosphere rises, causing global warming to accelerate. Global warming or the warming of Earth is due to an increased green-house effect [49]. Since our goal is to achieve sustainability the emission of greenhouse gases can allow us to achieve sustainability. Since it allows for sustainability, it will also allow for attracting good investment as in the long term, green-house emission is bad for the ecosystem [50].

\section{Methodology}

We initially identified critical factors affecting ESG investing; we reviewed past works and sought different expert opinions (inputs to structured self-interaction matrices (SSIMs)). We also reviewed and evaluated related articles and research studies for evaluation.

Next, we used ISM to develop a baseline model of associations among critical factors and performed the MICMAC analysis to group the factors. Our ISM seeks to determine the relationships among factors identified a through literature review or expert opinion as an issue or a problem. The ISM techniques we approached include brainstorming, nominal group techniques and face-to-face interviews yielding expert views regarding how to develop a contextual relationship among selected key factors. Here, we addressed the factors to consider for ESG investing. Factors determined through a literature review were reviewed by experts. No limit was imposed on the number of factors.

Table 1 lists the 10 factors identified, and Table 2 lists the ISM steps. The critical dimensions of ESG investing commences with ISM completion and concludes with MICMAC policy recommendations. A strong correlation is perceptible between the ISM model and the critical factors that have been identified.

Table 1. Numbers of factors evaluated in various reports.

\begin{tabular}{cc}
\hline S1. No & Factors \\
\hline F1. & Revenue Conservation (RC) \\
\hline F2. & Human Rights (HR) \\
\hline F3. & Good Governance (GG) \\
\hline F4. & Deforestation and Biodiversity (DB) \\
\hline F5. & Impact on Investment (II) \\
\hline F6. & Waste Management and Pollution Control \\
\hline F7. & (WMP) \\
\hline F8. & Corpact on Environment (IE) \\
\hline F9. & Greenhouse Emission (GHE) \\
\hline F10.
\end{tabular}


Table 2. ISM steps.

\begin{tabular}{|c|c|c|}
\hline S1. No. & Steps & Focus \\
\hline 1. & $\begin{array}{l}\text { Establishment of a Structural } \\
\text { Self-Interaction Matrix (SSIM) }\end{array}$ & $\begin{array}{l}\text { Driving pairwise relationships among } \\
\text { identified critical dimensions of ESG } \\
\text { factors and ESG investing }\end{array}$ \\
\hline 2. & Create a Reachability Matrix & Determine driving and dependent factors \\
\hline 3. & Level Partitioning & $\begin{array}{c}\text { Define structural levels (factors level } \\
\text { partitioning) }\end{array}$ \\
\hline 4. & ISM Modeling & $\begin{array}{l}\text { Develop an ISM model using a reachability } \\
\text { matrix and level partitioning }\end{array}$ \\
\hline 5. & MICMAC Analysis & $\begin{array}{l}\text { Classify critical dimensions of ESG } \\
\text { investing into four factors: drivers, } \\
\text { dependents, autonomous factors, and } \\
\text { linked factors via the MICMAC analysis }\end{array}$ \\
\hline
\end{tabular}

\subsection{ISM}

ISM is an agile and widely used approach taken by researchers in supplier selection, knowledge management, green supply chain management and energy conservation and is used by strategic decisionmakers in various organizations. To recognize/construct associations between factors affecting decision making when a particular problem arises is what ISM attempts to do. Then it seeks to solve the problem by considering the driving and dependency powers of each factor. The associations among factors are identified by experts and becomes the framework. Fewer experts are required compared with structural equation modeling or the Delphi method. However, ISM builds models that solve decision-making problems.

The numerous applications of ISM are listed in Table 3. Modeling proceeds as follows: (1) identification of relevant factors based on previous studies and expert opinion; (2) development of an SSIM, then a reachability matrix; (3) development of an SSIM, then a reachability matrix; (4) development of an SSIM, then a reachability matrix; (5) identifying uncertainty and the resulting moderations.

Table 3. Applications of ISM.

\begin{tabular}{cc}
\hline Techniques & Application \\
\hline ISM & Security System for Better Security Management in Railways [51] \\
\hline ISM & Analyzing the factors influencing integrated lean sustainable system [52] \\
\hline ISM & Manufacturing Sector [53] \\
\hline ISM & Modeling the Issues and Factors of Mobile App Development [54] \\
\hline ISM & Green Supply Chain Management [55] \\
\hline
\end{tabular}

\subsubsection{The SSIM}

The SSIMs finalized by experts provided the ISM inputs. The contextual relationships among the 10 factors were determined by the majority opinions on different web platforms. We came across the conclusion finalizing the contextual relationships after considering the nature, the objective and the majority opinion concerning the relationships of each problem between the factors.

The contextual association between two elements ( $\mathrm{s}$ and $\mathrm{t}$ ) is represented in one of four manners: (a) if s influences $t$, this is represented by $V$; (b) if $t$ influences $s$, this is represented by $\mathrm{A}$; (c) if $\mathrm{s}$ and $\mathrm{t}$ influence each other, this is represented by $\mathrm{X}$; and (d) if $\mathrm{s}$ and $\mathrm{t}$ are independent, this is represented by $\mathrm{O}$. For instance, waste management and pollution control F7 (WMP) influences the environment F8 (IE); therefore, the symbol used is V. Greenhouse gas emission F10 (GHE) has an impact on environment F8(IE); therefore, 
the symbol used is A. Revenue conservation F1 (RC) and deforestation and biodiversity F4 (DB) interact; the symbol used is X. The SSIM summary is presented in Table 4. The reachability matrix associated with the SSIMs is addressed further below.

Table 4. Structural self-interaction matrix.

\begin{tabular}{|c|c|c|c|c|c|c|c|c|c|c|}
\hline Factors & F1 & F2 & F3 & F4 & F5 & F6 & F7 & F8 & F9 & F10 \\
\hline $\mathrm{F} 1$ & & A & A & $x$ & $\mathrm{~V}$ & A & $x$ & $\mathrm{~V}$ & A & $\mathrm{V}$ \\
\hline F2 & & & A & V & $\mathrm{V}$ & $X$ & $\mathrm{~V}$ & $\mathrm{~V}$ & $x$ & $\mathrm{~V}$ \\
\hline F3 & & & & $\mathrm{V}$ & $\mathrm{V}$ & $\mathrm{V}$ & $\mathrm{V}$ & $\mathrm{V}$ & $\mathrm{V}$ & $\mathrm{V}$ \\
\hline F4 & & & & & $\mathrm{V}$ & A & $x$ & $\mathrm{~V}$ & A & $\mathrm{V}$ \\
\hline F5 & & & & & & A & A & A & A & A \\
\hline F6 & & & & & & & $\mathrm{V}$ & $\mathrm{V}$ & $x$ & V \\
\hline F7 & & & & & & & & V & A & $\mathrm{V}$ \\
\hline F8 & & & & & & & & & A & A \\
\hline F9 & & & & & & & & & & $\mathrm{V}$ \\
\hline F10 & & & & & & & & & & \\
\hline
\end{tabular}

\subsubsection{Reachability Matrix}

The four SSIM representations, $\mathrm{V}, \mathrm{A}, \mathrm{X}$, and $\mathrm{O}$, were then replaced by 1 or 0 in a reachability matrix, as follows: (a) the symbol V in the (s,t) position of the SSIM matrix was replaced by 1 and 0 in the $(\mathrm{s}, \mathrm{t})$ and $(\mathrm{t}, \mathrm{s})$ positions, respectively, of the reachability matrix; (b) in the $(\mathrm{s}, \mathrm{t})$ position of the SSIM matrix, the symbol A is replaced by 0 and 1 in the $(\mathrm{s}, \mathrm{t})$ and $(t, s)$ positions, respectively, of the reachability matrix; $(c)$ in the $(s, t)$ position of the SSIM matrix, the symbol $\mathrm{X}$ is replaced by 1 in both the $(\mathrm{s}, \mathrm{t})$ and $(\mathrm{t}, \mathrm{s})$ positions of the reachability matrix; and (d) the symbol $\mathrm{O}$ in the $(\mathrm{s}, \mathrm{t})$ position in the SSIM matrix is substituted by 0 in both the $(\mathrm{s}, \mathrm{t})$ and $(\mathrm{t}, \mathrm{s})$ positions of the reachability matrix.

Next, the transitivity of the reachability matrix was checked where transitivity refers to the fact that if factor F1 influences F2 and F2 influences F3, then F1 impacts F3. If the position $(i, j)$ of F1 impacts F3, the value becomes 1 . We calculate a factor by adding all values in the accommodating row for the driving power (DVP) and for the dependence power (DNP) by adding all values in the accommodating column. After factoring transitivity, the final version of the reachability matrix is shown in Table 5 . The subsequent steps (i.e., partition of different levels) then use the reachability matrix.

Table 5. Reachability matrix.

\begin{tabular}{cccccccccccc}
\hline Factors & F1 & F2 & F3 & F4 & F5 & F6 & F7 & F8 & F9 & F10 & Driving Power $t$ \\
\hline F1 & 1 & 0 & 0 & 1 & 1 & 0 & 1 & 1 & 0 & 1 & 6 \\
\hline F2 & 1 & 1 & 0 & 1 & 1 & 1 & 1 & 1 & 1 & 1 & 9 \\
\hline F3 & 1 & 1 & 1 & 1 & 1 & 1 & 1 & 1 & 1 & 1 & 10 \\
\hline F4 & 1 & 0 & 0 & 1 & 1 & 0 & 1 & 1 & 0 & 1 & 6 \\
\hline F5 & 0 & 0 & 0 & 0 & 1 & 0 & 0 & 0 & 0 & 0 & 1 \\
\hline F6 & 1 & 1 & 0 & 1 & 1 & 1 & 1 & 1 & 1 & 1 & 9 \\
\hline F7 & 1 & 0 & 0 & 1 & 1 & 0 & 1 & 1 & 0 & 1 & 6 \\
\hline F8 & 0 & 0 & 0 & 0 & 1 & 0 & 0 & 1 & 0 & 0 & 2 \\
\hline F9 & 1 & 1 & 0 & 1 & 1 & 1 & 1 & 1 & 1 & 1 & 9 \\
\hline F10 & 0 & 0 & 0 & 0 & 1 & 0 & 0 & 1 & 0 & 1 & 3 \\
\hline Dependence $s$ & 7 & 4 & 1 & 7 & 10 & 4 & 7 & 9 & 4 & 8 & \\
\hline
\end{tabular}




\subsubsection{Level Partition}

Next, the reachability and the antecedent sets for each element were developed based on the reachability matrix. The reachability set contains the factors themselves and factors impacted by other factors, and the antecedent set consists of the factors themselves and factors impacting those factors. The intersection set is the group of elements common to the antecedent and reachability sets. The procedure was iterated, when the antecedent and reachability sets were equal, the top factor was identified.

For example, level I is occupied by F5 due to the equality of the antecedent and reachability sets. Six iterations were performed when identifying the level of a factor. The level partition is shown in Table 6. All 10 factors are split into six levels. F3 occupies the sixth level and F5 occupies the first level; the other factors lie between these levels.

Table 6. Level partition.

\begin{tabular}{ccccc}
\hline Factors & Reachability Set & Antecedent Set & Intersection Set & Level \\
\hline F1 & $1,4,5,7,8,10$ & $1,2,3,4,6,7,9$ & $1,4,7$ & IV \\
\hline F2 & $1,2,4,5,6,7,8,9,10$ & $2,3,6,9$ & $2,6,9$ & V \\
\hline F3 & $1,2,3,4,5,6,7,8,9,10$ & 3 & 3 & VI \\
\hline F4 & $1,4,5,7,8,10$ & $1,2,3,4,6,7,9$ & $1,4,7$ & IV \\
\hline F5 & 5 & $1,2,3,4,5,6,7,8,9,10$ & 5 & I \\
\hline F6 & $1,2,4,5,6,7,8,9,10$ & $2,3,6,9$ & $2,6,9$ & V \\
\hline F7 & $1,4,5,7,8,10$ & $1,2,3,4,6,7,9$ & $1,4,7$ & IV \\
\hline F8 & 5,8 & $1,2,3,4,6,7,8,9,10$ & 8 & II \\
\hline F9 & $1,2,4,5,6,7,8,9,10$ & $2,3,6,9$ & $2,6,9$ & V \\
\hline F10 & $5,8,10$ & $1,2,3,4,6,7,9,10$ & 10 & III \\
\hline
\end{tabular}

\subsubsection{ISM Model}

The ISM of Figure 1 was developed based on the digraph and level partition table. A digraph exemplifies the interrelationships among elements at edges and nodes. Digraphs remove the transitive relationships between elements. The ISM is extracted from the combinative information of the digraph [56].

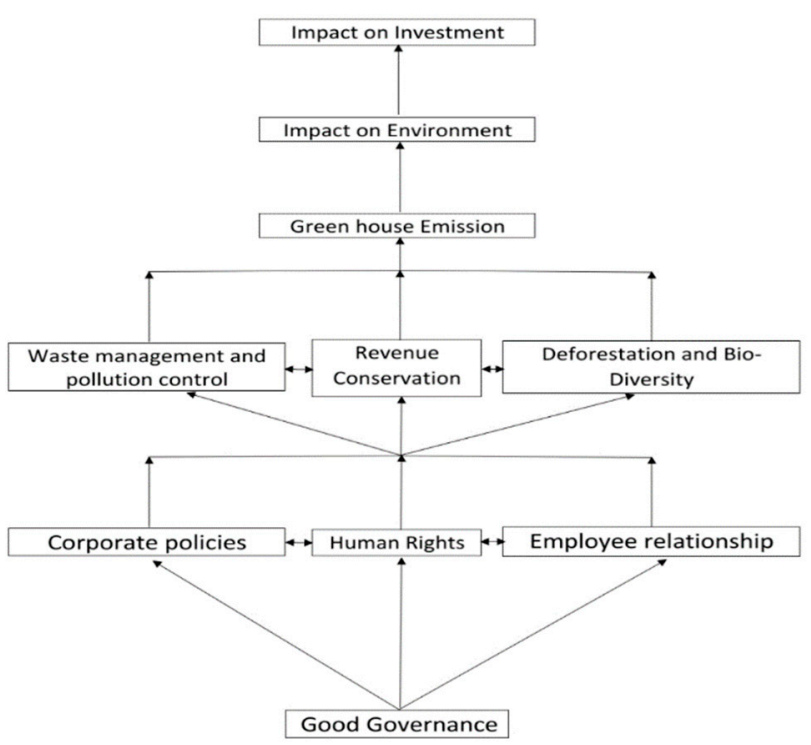

Figure 1. ISM model. 


\subsection{MICMAC Analysis}

MICMAC firstly requires factor dependence and driving powers as inputs [57]. Then it requires factor dependence and driving powers as inputs that categorizes the factors into four types (Figure 2). Autonomous variables (factors with weak dependence and driving powers) are shown in the first quadrant. Dependent variables (factors with strong dependence but weak driving powers) are shown in the second quadrant. Linkage variables (factors with strong dependence and driving powers) are shown in the third quadrant. Driving variables (factors with weak dependence powers and strong driving powers) appear in the fourth quadrant [58].

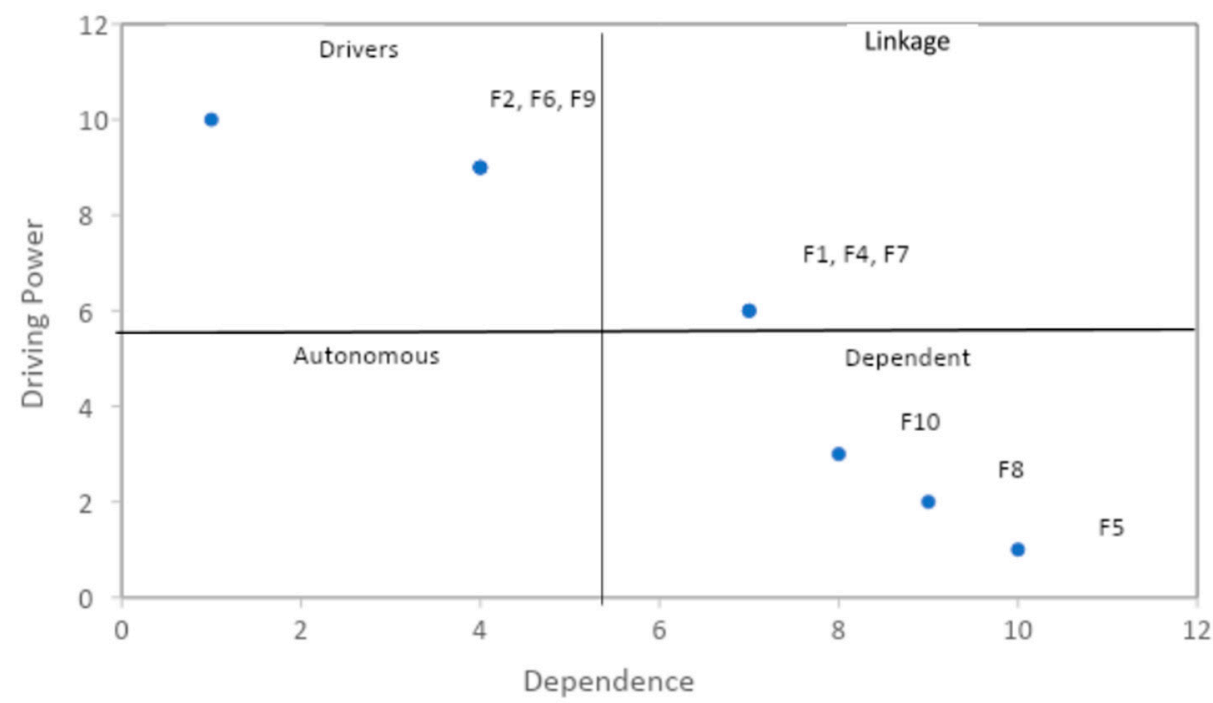

Figure 2. MICMAC analysis.

\section{Results and Discussions}

The linkages among elements affecting ESG investing were extensively examined and created in our study. We used the MICMAC analysis to identify crucial factors affecting ESG towards investment, and then methodically studied and created correlations between those elements in ISM. Through the investigation, we were able to determine factor dependence and driving powers.

In Figure 1, the ISM split all components into six tiers. The consideration of good governance (GG) (F3) is a fundamental part of ESG (which was positioned at the bottom of the hierarchy). In the long term, good governance (F3) drives level II with corporate policies (F9), employee relationship (F6), and human rights (F2) to achieve investment impact II (F5). Similarly, waste management and pollution control WMP (F7), revenue conservation (RC) (F1), and deforestation and biodiversity (DB) lead to level III (F4). This level III has an impact on greenhouse gas emissions (GHEs) (F10) in level IV. Then, in level $\mathrm{V}$, greenhouse emissions (GHEs) (F10) have an impact on the environment (IE) (F8). After realizing the impact on the environment (IE), the objective impact on investment (II) (F5) was finally realized at level VI (F8).

The MICMAC analysis, shown in Figure 2, divides the 10 identified factors into four portions. The autonomous zone is the initial section, which is based on low driving and minimal power dependence. From the identified factors, there is no autonomous component, implying that there is no unfocused factor. The second segment has a high degree of reliance and limited driving power. The main dependent elements are the impact on investment (II) (F5), the impact on the environment (IE) (F8), and greenhouse emission (GHE) (F10). The third segment is known as the linkage zone, which is unstable and builds with significant driving and dependent powers. Three factors are unstable in our analysis: revenue conservation (RC) (F1), deforestation and biodiversity (DB) (F4), and waste management and pollution control (WMP) (F7). Finally, in the fourth quadrant, 
variables such as good governance (F3), human rights (F2), employee relationships (ER) (F6), and corporate policy (CP) are recognized as major drivers.

Different authors have studied the ESG environment by using different methodologies to achieve the desired outcomes. Various challenges to integrate ESG investors' preferences in the clothing industry has been determined by a fuzzy multicriteria decision-making method and is focused on commercial solutions as the key factor [59]. The ISM analysis illustrates that the corporate policy, which is a governing commercial solution, is the key driver towards ESG and validates the outcomes of the previous research. Similarly return and risk with good governance ESG has been studied by previous researchers using the MCDM technique [60] and the same result was observed as in this research; that is good governance is the strangest driver to achieve the investment impact on ESG. Eccles et al., [61] focused the non-financial data and social construction as the crucial aspects of ESG by an in-depth literature analysis and this study observes that the non-financial performances, such as human rights, employee relationships, and corporate policy are influencing ESG toward investment. Similarly, the result showed that environmental impact is the key objective to achieve the investment impact which validates the outcome of the previous research where researchers focused on the environment factor for the construction of building. [62]. Some studies have also used the ISM model, which focuses on good governance with a proper management mission and vision as an important driver $[55,63]$. Good governance with a management vision drives environmental performance with green design and green manufacturing using ISM techniques [55]. Similarly, the management vision resulted as the major driver for organizational performance using the ISM analysis [63]. The outcome of this study shows that good governance is driving the investment impact through environmental impact which supports the results of previous studies $[55,63]$.

\section{Conclusions and Managerial Implications}

In recent years, public awareness of environmental, social, and corporate governance (ESG) concerns has grown, resulting in a shift in societal mindset that has changed asset management market circumstances. People have begun to rethink their environmental impact and consider the ramifications of their behavior on society as a whole.

Investors and partners are increasingly demanding products that promote environmental protection, or at the very least do not hurt the environment, recognize working conditions, and practice long-term corporate governance. New market participants take advantage of these issues and use them to set themselves apart from incumbent competitors, who are forced to change their strategy as a result. Politicians and regulators have begun to incorporate sustainability factors and an ESG framework, resulting in both new and amended regulatory requirements. Asset managers' value chains will need to undergo considerable transformations to remain in the new environment, affecting front-, middle-, and back-office services.

In today's world, sustainability reporting has evolved into a strategy that connects all stakeholders, from internal employees to external investors. These reports assist in revealing previously unfocused data as actual KPIs and industry standards for assessing a company's value offer. Businesses have begun to put themselves one step ahead of those that do not follow these practices by gathering high-quality qualitative and quantitative data, making them the most appealing to investors and clients alike.

The capacity to determine the factors that influence the market's value of a company and then judge the correctness of that valuation is critical to successful investing. Analysts are usually well-versed in the use of financial measures to decipher the drivers of corporate value and provide expert analysis of often complex accounting data. Nonfinancial considerations, such as environmental, social, and governance (ESG) concerns, have been increasingly important in determining the value of firms in recent years. Traditional financial analysis already accounts for certain "intangibles" such as goodwill, but it has struggled to incorporate additional dynamic, nonfinancial aspects. ESG variables encompass a wide range of inherent risks that might affect the valuation of stock, fixed-income, 
real estate, and infrastructure assets. The study delivers a unique contribution towards the investment impact of ESG by developing a structural diagraph with selected factors and pinpoints the driving strategic factors for immediate attention. This study has limitations and in the future more factors can be included to obtain more clarity. This model can be tested in the manufacturing industry to visualize the shortcomings to revise the model towards transparency. The study concludes that good governance, human rights, employee relationships, and corporate policy, lead to achieving investment impact through environmental impact. Our analysis shall provide companies with the information and tools needed to establish and expand the impact of their ESG policy in order to attract more investors seeking sustainability in their portfolio.

Author Contributions: Conceptualization, S.A. and S.T.; methodology, S.A. and S.T.; validation, S.A., S.T. and H.-C.K.; formal analysis, S.A., A.T., D.N. and S.T.; data curation, S.A. and S.T.; writing-original draft preparation, S.A., A.T. and D.N.; writing-review and editing, S.A. and S.T.; supervision, H.-C.K.; project administration, H.-C.K.; funding acquisition, H.-C.K. All authors have read and agreed to the published version of the manuscript.

Funding: This work was supported by the Commercializations Promotion Agency for R\&D Outcomes (COMPA) grant funded by the Korean Government (Ministry of Science and ICT) (R\&D project No.1711139492).

Institutional Review Board Statement: Not applicable.

Informed Consent Statement: All the participants gave their consent to participate in this study.

Data Availability Statement: Not applicable.

Conflicts of Interest: The authors declare no conflict of interest.

\section{References}

1. Anderson, D.R.; Anderson, K.E. Sustainability risk management. Risk Manag. Insur. Rev. 2009, 12, 25. Available online: http:/ / onlinelibrary.wiley.com/doi/10.1111/j.1540-6296.2009.01152.x/full (accessed on 19 July 2021). [CrossRef]

2. Reed, R.G.; Wilkinson, S.J. The increasing importance of sustainability for building ownership. J. Corp. Real Estate 2005, 7, 339-350. [CrossRef]

3. Kiron, D.; Kruschwitz, N.; Reeves, M.; Haanaes, K.; Goh, E. The Benefits of Sustainability-Driven Innovation. In Own the Future; Deimler, M., Lesser, R., Rhodes, D., Sinha, J., Eds.; Wiley Online Library: Hoboken, NJ, USA, 2012. [CrossRef]

4. de Francesco, A.J.; Levy, D. The impact of sustainability on the investment environment. J. Eur. Real Estate Res. 2008, 1, 72-87. [CrossRef]

5. Friede, G.; Busch, T.; Bassen, A. ESG and financial performance: Aggregated evidence from more than 2000 empirical studies. J. Sustain. Financ. Invest. 2015, 5, 210-233. [CrossRef]

6. Escrig-Olmedo, E.; Munoz-Torres, M.J.; Fernandez-Izquierdo, M.A. Socially responsible investing: Sustainability indices, ESG rating and information provider agencies. Int. J. Sustain. Econ. 2010, 2, 442-461. [CrossRef]

7. Schultz, A. Future Returns: Sustainable Investing is Turning Mainstream. Barrons. 17 November 2020. Available online: https:/ / www.barrons.com/articles / future-returns-sustainable-investing-is-turning-mainstream-01605640036 (accessed on 19 July 2021).

8. Drempetic, S.; Klein, C.; Zwergel, B. The Influence of Firm Size on the ESG Score: Corporate Sustainability Ratings Under Review. J. Bus. Ethics 2020, 167, 333-360. [CrossRef]

9. Xiao, Y.; Faff, R.; Gharghori, P.; Lee, D. An Empirical Study of the World Price of Sustainability. J. Bus. Ethics 2013, 114, 297-310. [CrossRef]

10. Platt, R.B.; Billings, W.D.; Gates, D.M.; Olmsted, C.E.; Shanks, R.E.; Tester, J.R. The Importance of Environment to Life. BioScience 1964, 14, 25-29. [CrossRef]

11. Sciarelli, M.; Cosimato, S.; Landi, G.; Iandolo, F. Socially responsible investment strategies for the transition towards sustainable development: The importance of integrating and communicating ESG. TQM J. 2021, 33, 39-56. [CrossRef]

12. Porter Michael, E.; Serafeim, G.; Kramer, M. Where ESG Fails. Institutional Investor, 16 October 2019.

13. Gallo, M.A.; Kenyon-Rouvinez, D. The Importance of Family and Business Governance. In Family Business. A Family Business Publication; Palgrave Macmillan: London, UK, 2005. [CrossRef]

14. Castañer, X.; Oliveira, N. Collaboration, coordination, and cooperation among organizations: Establishing the distinctive meanings of these terms through a systematic literature review. J. Manag. 2020, 46, 965-1001. [CrossRef]

15. Keding, C. Understanding the interplay of artificial intelligence and strategic management: Four decades of research in review. Manag. Rev. Q. 2020, 71, 91-134. [CrossRef] 
16. Kitsios, F.; Kamariotou, M. Artificial Intelligence and Business Strategy towards Digital Transformation: A Research Agenda. Sustainability 2021, 13, 2025. [CrossRef]

17. Kitsios, F.; Kamariotou, M. Mapping new service development: A review and synthesis of literature. Serv. Ind. J. 2020, 40, 682-704. [CrossRef]

18. Kitsios, F.; Kamariotou, M.; Talias, M.A. Corporate sustainability strategies and decision support methods: A bibliometric analysis. Sustainability 2020, 12, 521. [CrossRef]

19. Kraus, S.; Schiavone, F.; Pluzhnikova, A.; Invernizzi, A.C. Digital transformation in healthcare: Analyzing the current state-ofresearch. J. Bus. Res. 2021, 123, 557-567. [CrossRef]

20. Marikyan, D.; Papagiannidis, S.; Alamanos, E. A systematic review of the smart home literature: A user perspective. Technol. Forecast. Soc. Chang. 2019, 138, 139-154. [CrossRef]

21. Patel, A.B.; Desai, T.N. A systematic review and meta-analysis of recent developments in sustainable supply chain management. Int. J. Logist. Res. Appl. 2019, 22, 349-370. [CrossRef]

22. Shams, S.R.; Vrontis, D.; Chaudhuri, R.; Chavan, G.; Czinkota, M.R. Stakeholder engagement for innovation management and entrepreneurial development: A meta-analysis. J. Bus. Res. 2020, in press.

23. Vial, G. Understanding digital transformation: A review and a research agenda. J. Strateg. Inf. Syst. 2019, 28, 118-144. [CrossRef]

24. Jorgenson, D.W. The theory of investment behavior. In Determinants of Investment Behavior; Universities National Bureau Conference Series No. 19; Ferber, R., Ed.; Columbia University Press: New York, NY, USA, 1967.

25. Peylo, B.T.; Schaltegger, S. An equation with many variables: Unhiding the relationship between sustainability and investment performance. J. Sustain. Financ. Invest. 2014, 4, 110-126. [CrossRef]

26. Pedersen, L.H.; Fitzgibbons, S.; Pomorski, L. Responsible Investing: The ESG-efficient Frontier. J. Financ. Econ. 2020. [CrossRef]

27. Amel-Zadeh, A.; Serafeim, G. Why and How Investors Use ESG Information: Evidence from a Global Survey. Financ. Anal. J. 2018, 74, 87-103. [CrossRef]

28. Van Duuren, E.; Plantinga, A.; Scholtens, B. ESG Integration and the Investment Management Process: Fundamental Investing Reinvented. J. Bus. Ethics 2016, 138, 525-533. [CrossRef]

29. NatureVest; EKO Asset Management Partners. Investing in Conservation: A Landscape Assessment of an Emerging Market. 2014. Available online: http://www.jpmorganchase.com/corporate/Corporate-Responsibility/document/InvestingInConservation_ Report_r2.pdf (accessed on 27 July 2021).

30. Avila Foucat, V.S. Community-based ecotourism management moving towards sustainability, in Ventanilla, Oaxaca, Mexico. Ocean Coast. Manag. 2002, 45, 511-529. [CrossRef]

31. Weston, P.; Nnadi, M. Evaluation of Strategic and Financial Variables of Corporate Sustainability and ESG Policies on Corporate Finance Performance. J. Sustain. Financ. Invest. 2021, 1-17. [CrossRef]

32. Blanton, S.; Blanton, R. What Attracts Foreign Investors? An Examination of Human Rights and Foreign Direct Investment. J. Politics 2007, 69, 143-155. [CrossRef]

33. Spar, D. Foreign Investment and Human Rights. Challenge 1999, 42, 55-80. [CrossRef]

34. United Nations Economic and Social Commission for Asia and the Pacific: What is Good Governance? Available online: https:/ / www.unescap.org/sites/default/files/good-governance.pdf (accessed on 20 July 2021).

35. Mengistu, A.A.; Adhikary, B.K. Does good governance matter for FDI inflows? Evidence from Asian economies. Asia Pac. Bus. Rev. 2011, 17, 281-299. [CrossRef]

36. Paoli, G.D.; Wells, P.L.; Meijaard, E.; Struebig, M.J.; Marshall, A.J.; Obidzinski, K.; Slik, J.F. Biodiversity in the REDD. Why efforts to reduce anthropogenic carbon emissions from forest may undermine long-term biodiversity conservation in Indonesia. Carbon Balance Manag. 2010, 5. [CrossRef]

37. Spears, J. Deforestation issues in developing countries the case for an accelerated investment programme. Commonw. For. Rev. 1985, 64, 313-343. Available online: http:/ / www.jstor.org/stable/42606519 (accessed on 20 July 2021).

38. Paiva, P.F.P.R.; de Lourdes Pinheiro Ruivo, M.; da Silva Júnior, O.M.; de Nazare Martins Maciel, M.; Braga, T.G.M.; de Andrade, M.M.N.; dos Santos Junior, P.C.; da Rocha, E.S.; de Freitas, T.P.M.; da Silva Leite, T.V.; et al. Deforestation in Protect Areas in the Amazon: A Threat to Biodiversity. Biodivers. Conserv. 2020, 29, 19-38. [CrossRef]

39. Leins, S. 'Responsible investment': ESG and the post-crisis ethical order. Econ. Soc. 2020, 49, 71-91. [CrossRef]

40. Sultana, S.; Zulkifli, N.; Zainal, D. Environmental, Social and Governance (ESG) and Investment Decision in Bangladesh. Sustainability 2018, 10, 1831. [CrossRef]

41. Bloemer, J.; Odekerken-Schröder, G. The role of employee relationship proneness in creating employee loyalty. Int. J. Bank Mark. 2006, 24, 252-264. [CrossRef]

42. Tsui, A.S.; Wu, J.B. The new employment relation-ship versus the mutual investment approach: Implications for human resource management. Hum. Resour. Manag. 2005, 44, 115-121. [CrossRef]

43. Bernstein, J.D. Alternative approaches to pollution control and waste management. In Stand Alone Books; UNDP: Washington, DC, USA, 1993.

44. Brunner, P.H.; Rechberger, H. Waste to energy-Key element for sustainable waste management. Waste Manag. 2015, 37, 3-12. [CrossRef]

45. Oprean-Stan, C.; Oncioiu, I.; Iuga, I.C.; Stan, S. Impact of Sustainability Reporting and Inadequate Management of ESG Factors on Corporate Performance and Sustainable Growth. Sustainability 2020, 12, 8536. [CrossRef] 
46. Kamal, Y.; Deegan, C. Corporate Social and Environment-related Governance Disclosure Practices in the Textile and Garment Industry: Evidence from a Developing Country. Aust. Account. Rev. 2013, 23, 117-134. [CrossRef]

47. Sparkes, R.; Cowton, C.J. The Maturing of Socially Responsible Investment: A Review of the Developing Link with Corporate Social Responsibility. J. Bus. Ethics 2004, 52, 45-57. [CrossRef]

48. Grundström, G.; Miedel, I. Sustainable Investing: On the Relation between Sustainability Rating and Greenhouse Gas Emissions. Master's Thesis Dissertation, UMEA University, Umeå, Sweden, 2021.

49. de Boer, I.; Cederberg, C.; Eady, S.; Gollnow, S.; Kristensen, T.; Macleod, M.; Meul, M.; Nemecek, T.; Phong, L.; Thoma, G.; et al. Greenhouse gas mitigation in animal production: Towards an integrated life cycle sustainability assessment. Curr. Opin. Environ. Sustain. 2011, 3, 423-431. [CrossRef]

50. de Spiegeleer, J.; Höcht, S.; Jakubowski, D.; Reyners, S.; Schoutens, W. ESG: A new dimension in portfolio allocation. J. Sustain. Financ. Invest. 2021. [CrossRef]

51. Srivastava, A.; Swami, S.; Banwet, D. Interpretive Structural Modeling of Security Systems for Better Security Management in Railways. Traffic Saf. 2016, 4, 367-377.

52. Vinodh, S.; Ramesh, K.; Arun, C.S. Application of interpretive structural modelling for analysing the factors influencing integrated lean sustainable system. Clean Technol. Environ. Policy 2016, 18, 413-428. [CrossRef]

53. Pal, A.; Rajendran, J.; Behl, A. Application of ISM in the Manufacturing Sector. In Multi-Criteria Decision Analysis in Management; IGI Global: Hershey, PA, USA, 2020; pp. 28-45.

54. Pandey, M.; Litoriya, R.; Pandey, P. An ISM approach for modeling the issues and factors of mobile app development. Int. J. Softw. Eng. Knowl. Eng. 2018, 28, 937-953. [CrossRef]

55. Aich, S.; Tripathy, S. An interpretive structural model of green supply chain management in Indian computer and its peripheral industries. Int. J. Procure. Manag. 2014, 7, 239-256. [CrossRef]

56. Sushil, S. Interpreting the interpretive structural model. Glob. J. Flex. Syst. Manag. 2012, 13, 87-106. [CrossRef]

57. Sivaprakasam, R.; Selladurai, V.; Sasikumar, P. Implementation of interpretive structural modelling methodology as a strategic decision-making tool in a Green Supply Chain Context. Ann. Oper. Res. 2015, 233, 423-448. [CrossRef]

58. Raj, T.; Shankar, R.; Suhaib, M. An ISM approach for modelling the enablers of flexible manufacturing system: The case for India. Int. J. Prod. Res. 2008, 46, 6883-6912. [CrossRef]

59. Escrig-Olmedo, E.; Rivera-Lirio, J.M.; Muñoz-Torres, M.J.; Fernández-Izquierdo, M.Á. Integrating multiple ESG investors' preferences into sustainable investment: A fuzzy multicriteria methodological approach. J. Clean. Prod. 2017, 162, $1334-1345$. [CrossRef]

60. Lundström, E.; Svensson, C. Including ESG concerns in the portfolio selection process: An MCDM approach. In Applied Mathematics and Industrial Economics, First Level; KTH Royal Institute of Technology, SCI School of Engineering Sciences: Stockholm, Sweden, 2014.

Lundström, E.; Svensson, C. Including ESG concerns in the portfolio selection process: An MCDM approach. Dissertation. 2014.

61. Eccles, R.G.; Lee, L.-E.; Stroehle, J.C. The Social Origins of ESG: An Analysis of Innovest and KLD. Organ. Environ. 2020, 33, 575-596. [CrossRef]

62. Klumbytè, E.; Bliūdžius, R.; Medineckienè, M.; Fokaides, P.A. An MCDM Model for Sustainable Decision-Making in Municipal Residential Buildings Facilities Management. Sustainability 2021, 13, 2820. [CrossRef]

63. Tripathy, S.; Ray, P.K.; Sahu, S. Performance Measurement of R\&D is a Vaccine for Innovation Capability: Evidence from Indian Manufacturing organization. Int. J. Electron. Transp. 2011, 1, 76-95. 